\title{
Knowledge of Improved Package of Practices of Registered Flower Growers of Central Kashmir
}

\author{
Junaid Ayaz $^{1 *}$, Noor-ul-Islam Wani ${ }^{1 *}$, Rahat Ashraf Wani ${ }^{2}$, \\ A.H. Hakeem ${ }^{1}$ and Raja Aadil Usman ${ }^{2}$ \\ ${ }^{1}$ Division of Agriculture Extension and Communication, ${ }^{2}$ Division of Floriculture \& \\ Landscape Architecture, SKUAST-K, India \\ *Corresponding author
}

\section{A B S T R A C T}

\section{Keywords}

Registered flower growers, Randomly, Knowledge, Experience and cultivation practices

Article Info

Accepted:

20 August 2018 Available Online:

10 September 2018
The study was conducted in three districts of the Kashmir valley namely district Srinagar, district Budgam and district Ganderbal. Out of 300 registered flower growers, 100 registered flower growers were selected randomly by using random number table. The study revealed that the knowledge of the registered flowers increased with the increase in their educational qualification and their experience in flower growing and as such around 70 per cent of the registered flower growers had complete knowledge regarding various cultivation practices including method of propagation, planting method, application of manures and fertilizers and use of fungicides and insecticides.

\section{Introduction}

The total area under flower cultivation in world is 2.7 lakh ha, out of which the area under Europe is 44,444 ha, North America 22,388 ha, Asia and Pacific 215,386 ha, the Middle East and Africa 2,282 ha, Central and South Africa 17,605 ha. Flowers are grown under protected greenhouses conditions on an area of 46008 ha. India has maximum area under ornamental crops 88,600 ha, followed by china 59,527 ha, Indonesia 34,000 ha, USA 25,290 ha, Japan 21,218 ha, Brazil 10,285 ha, Taiwan 9,661 ha, Netherland 8,017 ha, UK 6,804 ha, Germany 6,621 ha, Colombia 4,757 ha, and Italy 765 ha (APEDA-2014).
India is bestowed with agro-climate and ecological conditions, which are favourable to grow all types of commercially important flowers generally found in different parts of the world. India is in an enviable position to become a leader in the world floriculture trade because of prevailing congenial location, diverse agro-climatic conditions and specific incentives given by the government and the department of floriculture in the country. The total area under flower crops in the country during 2014 was 255.02 thousand hectare with an annual production of $1754.49 \mathrm{Mt}$ loose flowers and $542.53 \mathrm{Mt}$ cut flowers. Bulbous crops, fresh and dried cut flowers dominate the floriculture exports from India. Rose, 
Marigold, Tuberose, Orchids and Chrysanthemum, Gladilous, Carnation, Orchids, Anthurium, Lily, Gerbera etc. are the main flowers exported from India. During the year 2014 the country had exported $3,09,26,023 \mathrm{Mt}$ of floriculture products to the world. The major importing countries of floriculture products are U.S.A, Germany, Netherland, U.K, Japan, Canada, \& U.A.E were the major importing countries of floriculture during the same period (Anonymous, 2015a). The state of Jammu and Kashmir is endowed with ample natural resources including soil, water, topographic diversity, climatic conditions and rich natural flora which facilitate the cultivation of wide range of flowers. The total area occupied under floriculture in the state is 494 hectare. The floriculture sector generates an annual turnover of Rs 5.02 crores in the state. (Diversification through floriculture 2016) Srinagar, Budgam and Jammu are the main districts of Jammu and Kashmir having maximum area and production of lose and cut flowers. The total number of registered flower growers in state are 725.Under greenhouse conditions the area under cut and flower in the state is 40 hectare. Srinagar, Jammu, Budgam, Ganderbal are the main district of Jammu and Kashmir having maximum area and production of loose and cut flowers. The total number of registered flower growers in Jammu and Kashmir is 725. In addition to this the area of cut and loose flowers in Jammu and Kashmir under greenhouse condition is 40 hectare (Anonymous, 2015b).

\section{Results and Discussion}

\section{Knowledge level of registered flower growers}

\section{Knowledge of registered flower growers about the hybrid varieties}

Table 1 reveals that a majority, 61 per cent of the registered carnation growers had complete knowledge about the hybrid varieties while as in case of Gladiolus growers, 53 per cent of the registered growers had complete knowledge about the hybrid varieties. So far as the gerbera is concerned, 47 per cent of the registered growers had complete knowledge about the hybrid varieties while as in case of Lilium grower, 49 per cent of the registered growers had complete knowledge about the hybrid varieties.

These findings were in conformity with the findings of Balasubramani (1997) and Reshmy (2001) (Fig. 1).

\section{Knowledge of the registered flower growers about plant to plant distance}

In case of Carnation, a vast majority 84 per cent of the registered carnation growers had complete knowledge about the plant to plant distance while as in case of gladiolus, 79 per cent of the registered growers had complete knowledge about plant to plant distance (Table 2). In case of Lilium, 68 per cent of the registered growers had complete knowledge about the plant to distance while as in case of gerbera 59 per cent of the registered growers had complete knowledge about plant to plant distance (Fig. 2).

\section{Knowledge of registered flower growers about the critical stage for irrigation}

Data in the table 3 reveals that, 73 per cent of the registered carnation growers had complete knowledge about critical stage of irrigation. While as 65 per cent of the gladiolus growers had complete knowledge about the critical stage for irrigation.

In case of Lilium, 51 per cent of the registered growers had complete knowledge about the critical stage for irrigation and in case gerbera 45 per cent of the registered flower growers had complete knowledge about the critical stage for irrigation (Fig. 3). 
Table.1 Knowledge of registered flower growers about the hybrid varieties

\begin{tabular}{|l|l|l|}
\hline \multicolumn{2}{|c|}{$(\mathrm{N}=100)$} \\
\hline Came of the Crop & Frequency* & Percentage \\
\hline Gladiolus & 61 & 61 \\
\hline Gerbera & 53 & 53 \\
\hline Lilium & 47 & 47 \\
\hline
\end{tabular}

*Multiple responses of respondent.

Table.2 Knowledge of registered flower growers about plant to plantdistance

\begin{tabular}{|l|l|l|}
\hline Name of the Crop & Frequency** & Percentage \\
\hline Carnation & 84 & 84 \\
\hline Gladiolus & 79 & 79 \\
\hline Gerbera & 59 & 59 \\
\hline Lilium & 68 & 68 \\
\hline
\end{tabular}

$(\mathrm{N}=100)$

* Multiple responses of respondents.

Table.3 Knowledge of registered flower growers about the critical stage for irrigation

\begin{tabular}{|l|l|l|}
\hline Name of the Crop & Frequency** & Percentage \\
\hline Carnation & 73 & 73 \\
\hline Gladiolus & 65 & 65 \\
\hline Gerbera & 45 & 45 \\
\hline Lilium & 51 & 51 \\
\hline
\end{tabular}

$(\mathrm{N}=100)$

Table.4 Knowledge of registered flower growers about the propagation method

\begin{tabular}{|l|l|l|}
\hline Name of the Crop & Frequency** & Percentage \\
\hline Carnation & 93 & 93 \\
\hline Gladiolus & 89 & 89 \\
\hline Gerbera & 91 & 91 \\
\hline Lilium & 75 & 75 \\
\hline
\end{tabular}

*Multiple responses of respondents.

Table.5 Knowledge of registered flower growers about the dosage of fertilizers

\begin{tabular}{|l|l|l|}
\hline Name of the Crop & Frequency* & Norcentage \\
\hline Carnation & 61 & 61 \\
\hline Gladiolus & 46 & 46 \\
\hline Gerbera & 49 & 49 \\
\hline Lilium & 53 & 53
\end{tabular}

*Multiple responses of respondents. 
Table.6 Knowledge of registered flower growers about the diseases

\begin{tabular}{|l|l|l|}
\hline Name of the Crop & Frequency* & Percentage \\
\hline Carnation & 48 & 48 \\
\hline Gladiolus & 39 & 39 \\
\hline Gerbera & 41 & 41 \\
\hline Lilium & 52 & 52
\end{tabular}

*Multiple responses of respondents.

Table.7 Knowledge of registered flower growers about the insect pests

\begin{tabular}{|l|l|l|}
\hline Name of the Crop & Frequency** & Percentage \\
\hline Carnation & 47 & 47 \\
\hline Gladiolus & 40 & 40 \\
\hline Gerbera & 39 & 39 \\
\hline Lilium & 55 & 55 \\
\hline
\end{tabular}

*Multiple responses of respondents.

Table.8 Knowledge of registered flower growers about fungicides to control the diseases

Name of the Crop

Frequency*

\section{Percentage}

\section{Carnation}

Gladiolus

Gerbera

Lilium

\begin{tabular}{|l|l|}
\hline 77 & 77 \\
\hline 68 & 68 \\
\hline 59 & 59 \\
\hline 83 & 83 \\
\hline
\end{tabular}

$(\mathrm{N}=100)$

*Multiple responses of respondents.

Table.9 Knowledge of registered flower growers about the insecticides to control the insect pests

Name of the Crop

Frequency*

\section{Percentage}

\begin{tabular}{l|l|}
\hline Carnation \\
\hline Gladiolus
\end{tabular}

\begin{tabular}{l}
67 \\
\hline 58
\end{tabular}

\section{Gerbera}

49

67

58

Lilium

76

49

76

*Multiple responses of respondents. 
Fig.1 Knowledge of registered flower growers about the hybrid varieties

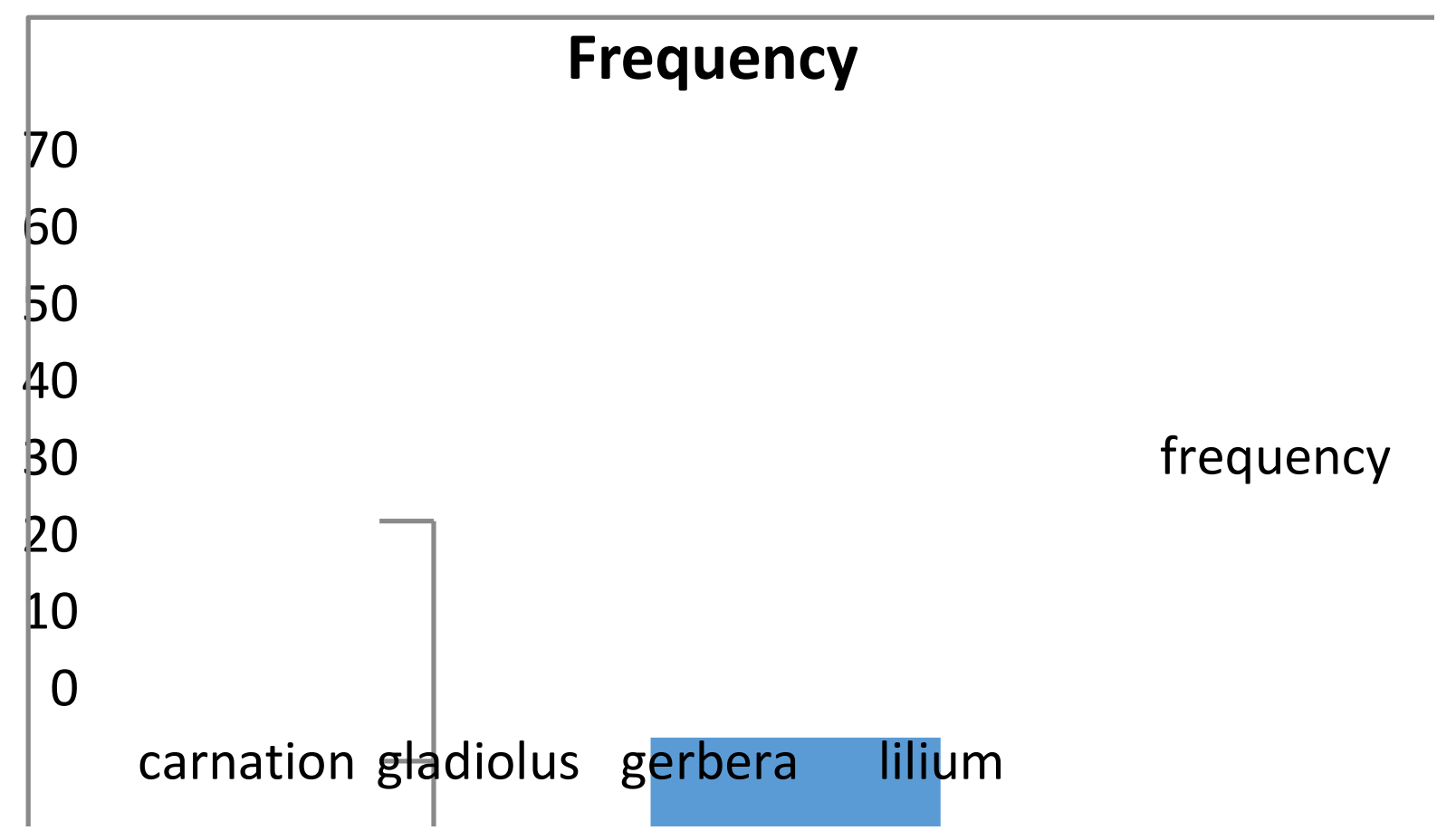

Fig.2 Knowledge of registered flower growers about plant to plant distance

\section{Frequency}

100

80

60

40

frequency

20

0

carnation gladiolus gerbera lilium 
Fig.3 Knowledge of registered flower growers about the critical stage for irrigation

\section{Frequency}

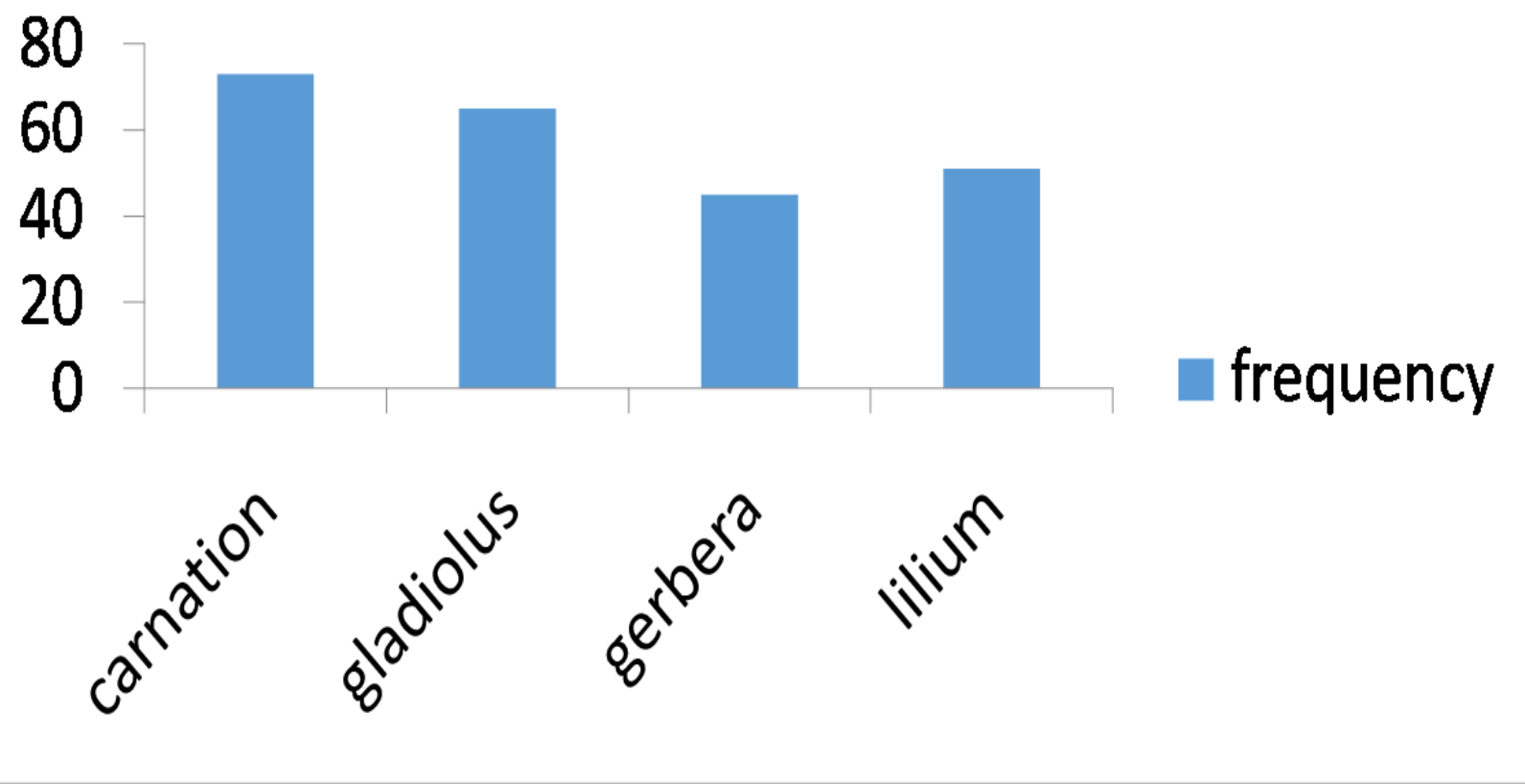

Fig.4 Knowledge of registered flower growers about the propagation method

\section{Frequency}

100.00

80.00

60.00

40.00

20.00

frequen...

0.00
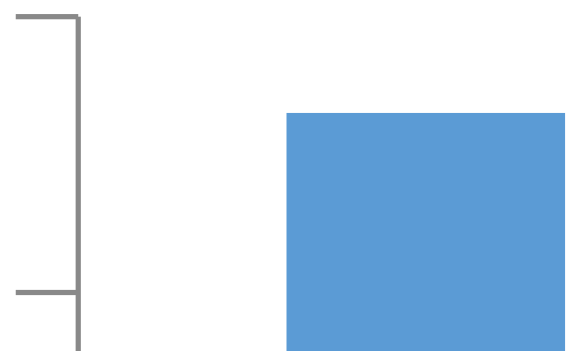
Fig.5 Knowledge of registered flower growers about the dosage of fertilizers

\section{Frequency}

70

60

50

40

30

frequency

20

10

0

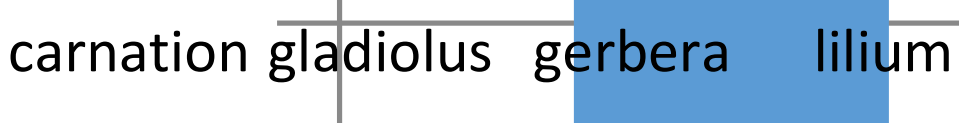

Fig.6 Knowledge of registered flower growers about the diseases

\section{Frequency}

50

50

40

30

20

10

0

carnation gladiolus gerbera lilium 
Fig.7 Knowledge of registered flower growers about the insect pests

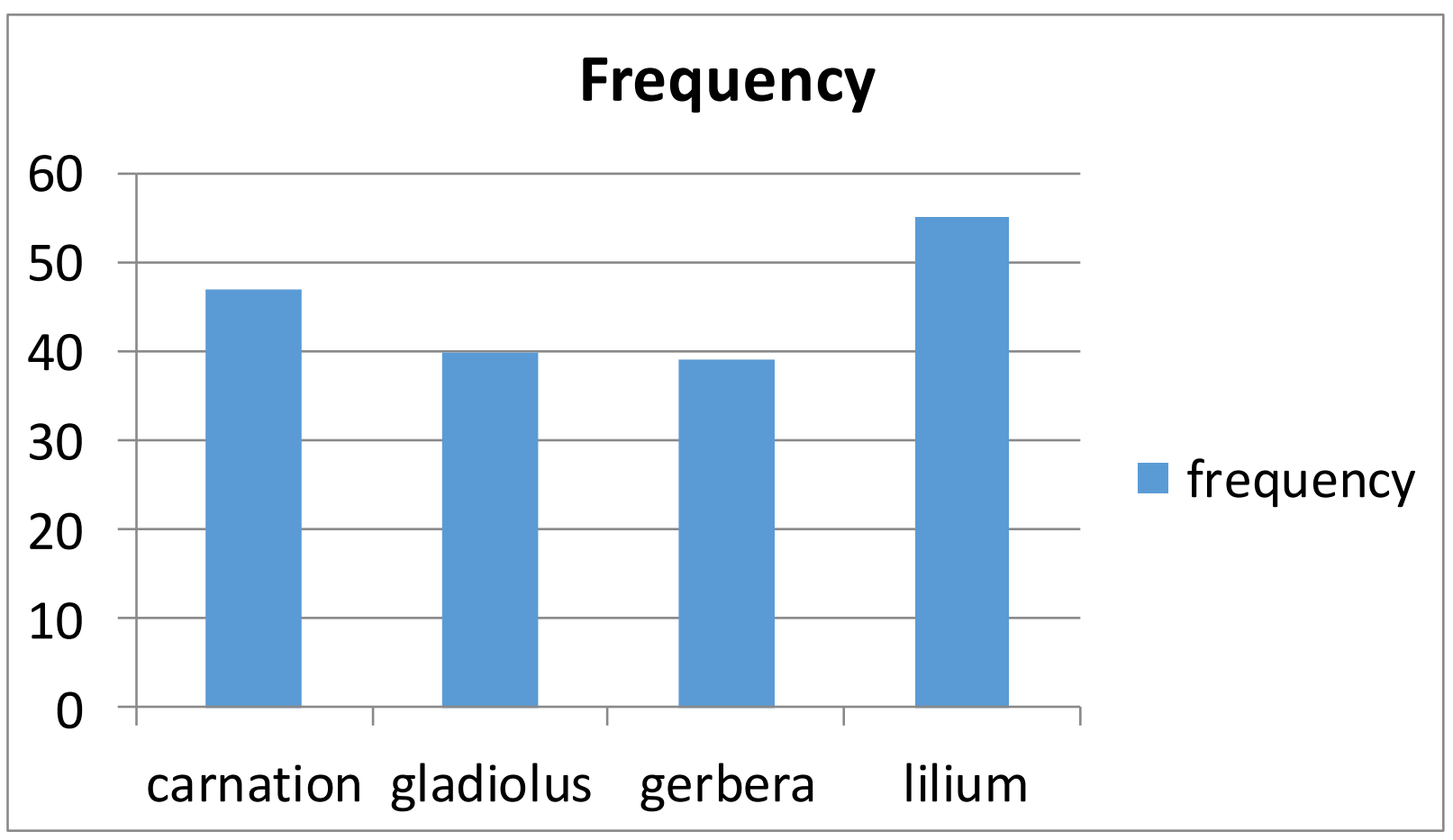

Fig.8 Knowledge of registered flower growers about fungicides to control the diseases

\section{Frequency}

100

80

60

40

frequency

20

0

carnation gladiolus gerbera lilium 
Fig.9 Knowledge of registered flower growers about the insecticides to control the insect pests

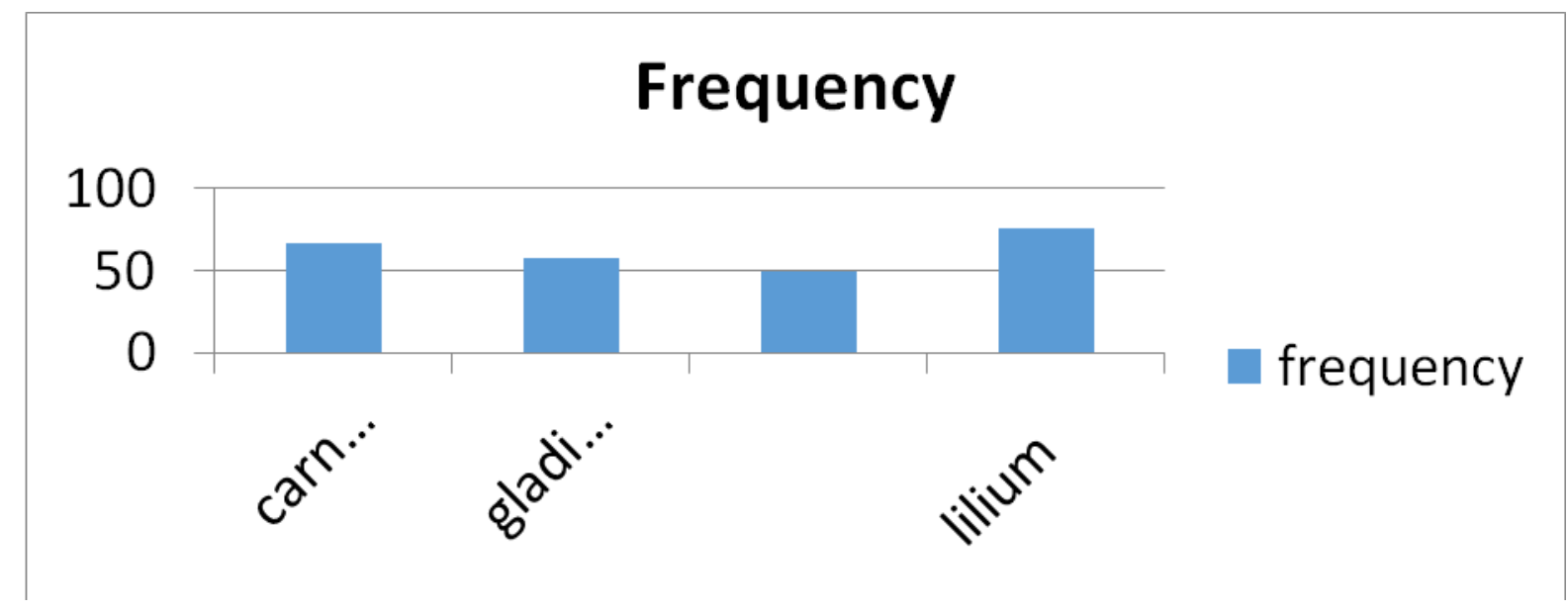

Knowledge of registered flower growers about the propagation method

Data in the table 4 reveals that 93 per cent of carnation growers had knowledge about the propagation method while as 89 per cent, 91 per cent and 75 per cent of gladiolus, gerbera and Lilium growers had knowledge about propagation methods (Fig. 4).

Knowledge of registered flower growers about the dosage of fertilizers

In case of carnation, 61 per cent of the registered flower growers had complete knowledge about the dosage of fertilizers and 53 per cent of the Lilium growers had complete knowledge (Table 5). In case of gerbera, 49 per cent of the registered flower growers had complete knowledge while as in case of gladiolus 46 per cent of the registered flower growers had complete knowledge about the dosage of fertilizers (Fig. 5).

Knowledge of registered flower growers about the diseases

In case of Lilium, 52 per cent of the registered flower growers had complete knowledge about the diseases and 48 per cent of the carnation growers had complete knowledge
(Table 6). In case of gerbera, 41 per cent of the registered flower growers had complete knowledge while as in case of gladiolus 39 per cent of the registered flower growers had complete knowledge about the diseases (Fig. $6)$.

\section{Knowledge of registered flower growers about the insect pests}

In case of Lilium, 55 per cent of the registered flower growers had complete knowledge about the insect pests and 47 per cent of the carnation growers had complete knowledge. In case of gladiolus, 40 per cent of the registered flower growers had complete knowledge while as in case of gerbera 39 per cent of the registered flower growers had complete knowledge about the insect pests (Fig. 7 and Table 7).

\section{Knowledge of registered flower growers about the fungicides to control the diseases}

In case of Lilium, a majority 83 of the registered flower growers had complete knowledge about the fungicides to control the diseases and 77 per cent of the carnation growers had complete knowledge. In case of gladiolus, 68 per cent of the registered flower growers had complete knowledge while as in 
case of gerbera 59 per cent of the registered flower growers had complete knowledge about the fungicides to control the diseases in gerbera (Fig. 8 and Table 8 ).

\section{Knowledge of registered flower growers} about the insecticides to control insect pests

In case of Lilium, a majority 76 of the registered flower growers had complete knowledge about the insecticides to control the diseases and 67 per cent of the carnation growers had complete knowledge. In case of gladiolus, 58 per cent of the registered flower growers had complete knowledge while as in case of gerbera 49 per cent of the registered flower growers had complete knowledge about the insecticides to control the diseases in gerbera (Fig. 9 and Table 9).

More than 60 per cent of carnation growers had knowledge of hybrids varieties, whereas knowledge possessed by the registered flower growers regarding hybrids of Lilium, Gladiolus and Gerbera 59, 53 and 47 percent respectively. Knowledge regarding planting distance was possessed by maximum number of carnation growers 84 per cent, and minimum number of Gerbera growers 59 per cent, whereas 79 per cent gladiolus growers and 68 per cent Lilium growers had knowledge about planting distance. About 73 percent of carnation growers, whereas 65 percent of Gladiolus growers, 51 percent of Lilium growers and 45 percent of Gerbera growers possessed correct knowledge about critical stage of irrigating the crop. About 90 per cent of registered flower growers possessed the knowledge of propagation method of cut flowers. About 50 per cent of Gladiolus, Gerbera, Lilium growers possessed the correct knowledge of fertilizer dosage and more than 60 per cent of carnation growers possessed the correct knowledge about fertilizer application. About 50 per cent of the registered flower growers carnation, Lilium possessed the knowledge of diseases in crops, whereas only about 40 per cent of the Gladiolus and Gerbera growers had the knowledge about the diseases of crops. Only about 50 per cent of registered flower growers possessed the knowledge of insect pest of crops. About the $3 / 4^{\text {th }}$ of registered flower growers had knowledge about various fungicides for controlling the diseases. About 60 per cent of registered flower growers had knowledge of insecticides for control the insect pest.

\section{References}

Anonymous, 2015(a). Present Status and Prospects of Floriculture in Jammu and Kashmir, ICAR Directorate of Floriculture Research, Pune-411005 (Maharashtra), pp. 1-21.

Anonymous, 2015(b). Present Status and Prospects of Floriculture in Jammu and Kashmir, ICAR Directorate of Floriculture Research Pune-411005 (Maharashtra), pp. 22-40.

APEDA, 2014. Agricultural and Processed Food Products Export Development Authority.

Balasubramani, N. 1997. Knowledge and adoption behavior of rubber growers in Belthangadi taluk of Dakshina Kannada district. M. Sc. (Agri.) Thesis, University of Agricultural Sciences, Bangalore.

Borude, S. V. 1992. An impact of Dairy Cooperative Society on Socio-economic Development of Member Farmers. Thesis submitted to Mahatma Phule Krishi Vidyapeeth, Rahuri, Maharashtra State.

Kumaran, M. Ponnusamy, K. and Krishnan, M., 2004. Utilization of information sources by shrimp farmers. Indian Journal of Extension Education, 40(12): 63-66.

Raut, D. R. 1985. A study of the member 
farmers of Parvara Sahkari Doodh Vyavasyik Santha of Ahmadnagar District and Problem faced by them in Dairy Occupation M. Sc. Thesis submitted to Mahatma Phule Krishi Vidyapeeth, Rahuri, Maharashtra State.

Reshmy, C. 2001. A study on sustainability of coconut and banana intercropping in Kerla - An analysis. M. Sc. Thesis submitted to university of Agricultural Sciences, Banglore, Karnataka, India.

Vedamurthy, H. S., 2002. A study on the management of Areca Gardens and marketing pattern preferred by the Areca nut growers of Shimoga district in Karnataka. M. Sc. Thesis submitted to university of Agricultural sciences, Bangalore, Karnataka, India.

Yogananda, H. G. 1992. A study on knowledge level, adoption behaviour and training needs of coconut growers. M. Sc. Thesis submitted to university of Agricultural sciences, Bangalore, Karnataka, India.

\section{How to cite this article:}

Junaid Ayaz, Noor-ul-Islam Wani, Rahat Ashraf Wani, A.H. Hakeem and Raja Aadil Usman. 2018. Knowledge of Improved Package of Practices of Registered Flower Growers of Central Kashmir. Int.J.Curr.Microbiol.App.Sci. 7(09): 2901-2911. doi: https://doi.org/10.20546/ijcmas.2018.709.360 